\title{
Peptide-equipped tobacco mosaic virus templates for selective and controllable biomineral deposition
}

\author{
Klara Altintoprak ${ }^{1}$, Axel Seidenstücker ${ }^{2}$, Alexander Welle ${ }^{3,4}$, Sabine Eiben ${ }^{1}$, \\ Petia Atanasova ${ }^{5}$, Nina Stitz ${ }^{5}$, Alfred Plettl ${ }^{2}$, Joachim Bill ${ }^{5}$, Hartmut Gliemann ${ }^{4}$, \\ Holger Jeske ${ }^{1}$, Dirk Rothenstein ${ }^{5}$, Fania Geiger ${ }^{1}$ and Christina Wege ${ }^{* 1}$
}

\section{Full Research Paper}

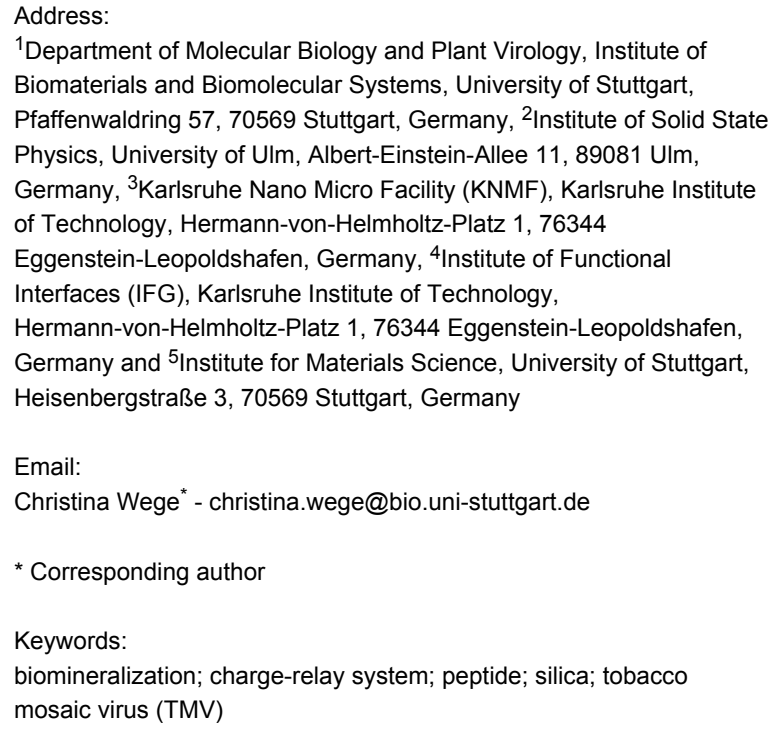

${ }^{1}$ Department of Molecular Biology and Plant Virology, Institute of Biomaterials and Biomolecular Systems, University of Stuttgart, Pfaffenwaldring 57, 70569 Stuttgart, Germany, ${ }^{2}$ Institute of Solid State Physics, University of Ulm, Albert-Einstein-Allee 11, 89081 Ulm, Germany, ${ }^{3}$ Karlsruhe Nano Micro Facility (KNMF), Karlsruhe Institute of Technology, Hermann-von-Helmholtz-Platz 1, 76344 Eggenstein-Leopoldshafen, Germany, ${ }^{4}$ Institute of Functional Interfaces (IFG), Karlsruhe Institute of Technology, Hermann-von-Helmholtz-Platz 1, 76344 Eggenstein-Leopoldshafen, Germany and ${ }^{5}$ Institute for Materials Science, University of Stuttgart, Heisenbergstraße 3, 70569 Stuttgart, Germany

Email:

Christina Wege* - christina.wege@bio.uni-stuttgart.de

* Corresponding author

Keywords:

biomineralization; charge-relay system; peptide; silica; tobacco

mosaic virus (TMV)

Beilstein J. Nanotechnol. 2015, 6, 1399-1412. doi:10.3762/bjnano.6.145

Received: 24 March 2015

Accepted: 29 May 2015

Published: 25 June 2015

This article is part of the Thematic Series "Towards multifunctional inorganic materials: biopolymeric templates".

Associate Editor: K. Koch

(C) 2015 Altintoprak et al; licensee Beilstein-Institut.

License and terms: see end of document.

\begin{abstract}
The coating of regular-shaped, readily available nanorod biotemplates with inorganic compounds has attracted increasing interest during recent years. The goal is an effective, bioinspired fabrication of fiber-reinforced composites and robust, miniaturized technical devices. Major challenges in the synthesis of applicable mineralized nanorods lie in selectivity and adjustability of the inorganic material deposited on the biological, rod-shaped backbones, with respect to thickness and surface profile of the resulting coating, as well as the avoidance of aggregation into extended superstructures. Nanotubular tobacco mosaic virus (TMV) templates have proved particularly suitable towards this goal: Their multivalent protein coating can be modified by high-surface-density conjugation of peptides, inducing and governing silica deposition from precursor solutions in vitro. In this study, TMV has been equipped with mineralization-directing peptides designed to yield silica coatings in a reliable and predictable manner via precipitation from tetraethoxysilane (TEOS) precursors. Three peptide groups were compared regarding their influence on silica polymerization: (i) two peptide variants with alternating basic and acidic residues, i.e. lysine-aspartic acid (KD) $)_{x}$ motifs expected to act as charge-relay systems promoting TEOS hydrolysis and silica polymerization; (ii) a tetrahistidine-exposing polypeptide $\left(\mathrm{CA}_{4} \mathrm{H}_{4}\right)$ known to induce silicification due to the positive charge of its clustered imidazole side chains; and (iii) two peptides with high $\mathrm{ZnO}$ binding affinity. Differential effects on the mineralization of the TMV surface were demonstrated, where a (KD) $x$ charge-relay
\end{abstract}


peptide (designed in this study) led to the most reproducible and selective silica deposition. A homogenous coating of the biotemplate and tight control of shell thickness were achieved.

\section{Introduction}

Amorphous silica $\left(\mathrm{SiO}_{2}\right)$ precipitated from silicate precursor sols comprises a wide range of versatile materials applied in various technological approaches, for example, as a structural modifier or filler in rubber [1], food [2,3] or healthcare products [4], bioceramics for medical purposes [5], mesoporous nanoparticulate or tubular drug delivery systems as reviewed in [6], sensor surfaces [7], or biocatalytic formulations as reviewed in [8]. An important focus of research and industry lies on the development of nanoscale materials, enabling the further miniaturization of devices and effector units, in addition to a reduced consumption of resources. In the field of functional mineral synthesis, significant progress has been made in using nanodimensional biological templates, allowing specific coating with inorganic materials to yield hybrid particles of predetermined structure and composition [9-11]. The surfaces of optimal templates nucleate and direct the formation of inorganic materials from suitable precursors, resembling a natural matrixmediated mineral deposition in living organisms known also as "biologically controlled mineralization" [12,13]. Such bioinspired mineralization approaches can accomplish precise coating processes and offer several benefits such as environmentally friendly fabrication routes and reaction parameters compatible with biological structures, namely low synthesis temperature and aqueous deposition media. In this context, tube- or rod-like templates of high aspect ratio are of particular interest, since they enable the fabrication of elongated nanostructures, which are otherwise difficult to obtain. This is because chemical synthesis or technical approaches applied at mild conditions commonly generate spherical structures [14]. Mineral nanofibers of predetermined size are of major importance for the preparation of functional films and extended 3D materials. Hence, anisotropic scaffolds such as high molecular weight polymers [15], carbon nanotubes [16], peptide nanotubes [17], certain plant viruses [18-21], filamentous bacteriophages [22,23], and bacterial flagellae [24] have been evaluated for their applicability on a technical scale. To achieve control over mineral precipitation, the modification of the template by chemical conjugation of peptides [16], poly(ethylene glycol) (PEG) [22], aniline [25,26], or succinamate [27] has been reported.

Virus-based templates have gained especially important roles in the synthesis of organic-inorganic hybrid nanostructures. They combine several advantages, namely high availability, robustness and an exact replication of the particle shape and dimension, which are genetically determined and result in a narrow size distribution. Different species such as the fibrous bacteriophage M13, icosahedral cowpea mosaic virus (CPMV), or tubular tobacco mosaic virus (TMV) were used as templates for coating with inorganic materials including Pt, Au [28], Ag [29,30], $\mathrm{Pd}[31,32], \mathrm{TiO}_{2}$ [33], $\mathrm{SiO}_{2}$ [34], $\mathrm{NiO}$ [35], $\mathrm{CdS}$ [21], $\mathrm{CoPt}, \mathrm{FePt}, \mathrm{ZnS}$ [27,36] and $\mathrm{ZnO}$ [37-39]. Among the virusbased templates, plant viruses are especially suitable nanostructured scaffolds because of their biological safety for humans, animals, and their commensal bacteria. TMV is a widespread plant-infecting pathogen, which can be isolated in large amounts from susceptible plants [40]. TMV particles are highly ordered, supramolecular complexes, consisting of a singlestranded helical RNA and $\approx 2130$ identical coat protein $(\mathrm{CP})$ subunits arranged around the RNA molecule, which is completely buried inside the protein shell [41-46]. The viral particle has an average length of $300 \mathrm{~nm}$ and an outer and inner (channel) diameter of $18 \mathrm{~nm}$ and $4 \mathrm{~nm}$, respectively. TMV has become a powerful building block in bionanotechnology due to its tube-like structure, high stability under a wide range of different conditions (e.g., $\mathrm{pH}$, temperature, solvent), low production costs and multivalent CP surface $[18,47,48]$.

The CP subunits of TMV can be genetically or chemically modified for the presentation of effector molecules [35,49-52]. Modified TMV templates maintain their 3D structure along with preserved particle stability, which is a prerequisite for the subsequent mineralization of inorganic materials. Furthermore, the length and also the overall shape of TMV-derived particles can be altered by means of engineered, non-natural RNA molecules, supporting the assembly of artificial, non-infectious, TMV-like nucleoprotein tube systems. This technology was even refined to allow the production of kinked boomerang, branched tetrapod and multiarmed nanostar structures [53,54], or into particles fashioned evenly with mixtures of two or more functional groups at predefined ratios [51].

To vary and control the deposition of inorganic minerals on TMV templates, extensive modifications of the surface amino acids are desirable. They enable defined alterations of the outer TMV-CP surface charge and the introduction of specific amino acid motifs, guiding the nucleation and growth of mineral coatings around the TMV core. This is in analogy to natural biomineralization-directing protein domains identified for various organisms [55-59]. Direct genetic modification of the TMV-CP sequence is, however, limited in view of the extent of alteration tolerated by virus particles upon their multiplication in plants, 
regarding number and composition of exchanged or inserted amino acids. In addition, high-throughput screening of different surface-expressed peptides is restricted upon TMV "farming" due to the required 10-14 days for TMV mutant accumulation. Bacterially expressed CP can be engineered to a much higher extent and integrated into TMV-like particles reconstituted in vitro in substantial amounts [51]. However, purification of such protein types from the bacteria cultures is much less efficient compared to CP isolation from intact TMV particles from leaf tissues.

Therefore, we have followed a third strategy and made use of plant-enriched, moderately engineered TMV templates, exposing selectively addressable reactive surface groups. These were subjected to chemical conjugation of synthetic peptides meant to regulate subsequent coating with silica (workflow indicated in Figure 1). This procedure is insensitive to both size and sequence of the peptide of choice, and the generation of various types of decorated TMV rods is fast. The amino acid sequences employed had been previously delimited by phage display to affect mineralization in our work [60] or by other researchers [17], or were predicted to influence silica deposition based on the literature [61]. Control experiments were carried out in parallel with bare TMV equally treated, in order to assess its capacity for silica nucleation in the absence of additional peptide domains.
Generally, it still remains a challenge to predictably, selectively and uniformly coat individual nanotemplate particles with silica. For this purpose, sol-gel condensation from precursors in alcoholic solutions seems most viable according to the conditions established by Stöber et al. [62] for the fabrication of plain silica spheres. Reaction parameters such as time, temperature, $\mathrm{pH}$, solvent composition and precursor, as well as catalyst concentration, affect the thickness of the mineral coating, in interdependence with the chemistry and charge distribution of the surface of the core $[22,26,27,63,64]$. During the mineralization process, great effort is needed to avoid non-templated byproducts, as well as aggregation, re-organization and precipitation of the templates into extended superstructures of amorphous silica-template composites.

Several earlier studies have demonstrated that native TMV capsids are effective biological nucleation cores for the deposition of mineral layers from silicate sols on their surfaces. This is typically carried out via hydrolysis and condensation of tetraethoxysilane (also known as tetraethylorthosilicate, TEOS) in alcohol-containing media (see Figure 1 for the mechanistic scheme). Obviously, the viral coating (which exhibits patches of both positively and negatively charged amino acids in nanometric vicinity to each other) is prone to silica deposition by itself. Concomitant with silicification reactions, however, TMV particles presented extensive rearrangement into head-to-tail a)

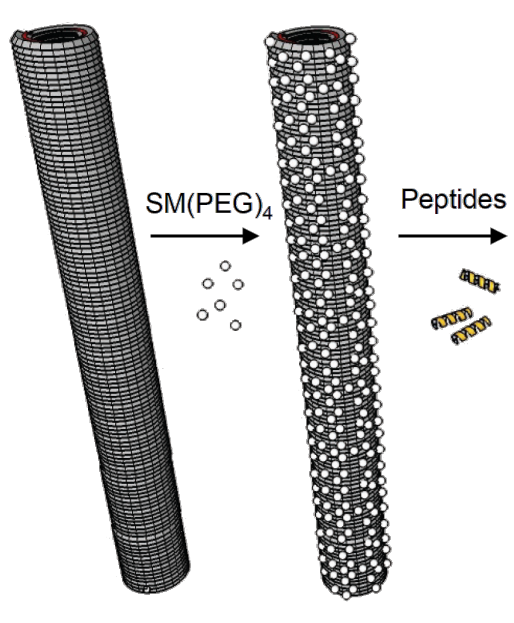

c)

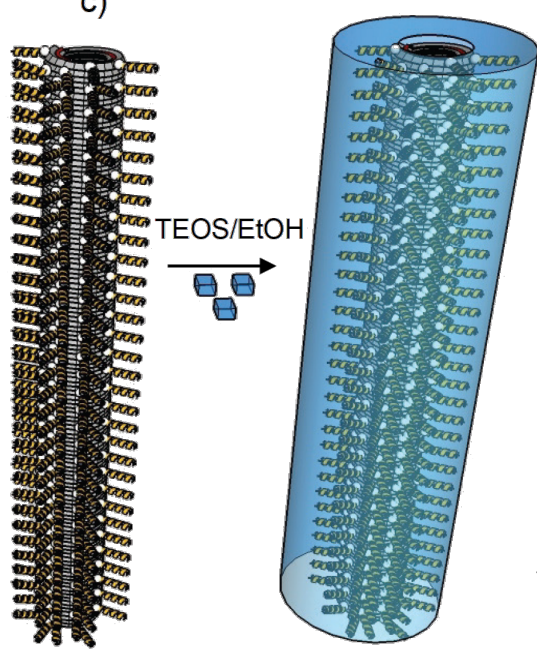

d)

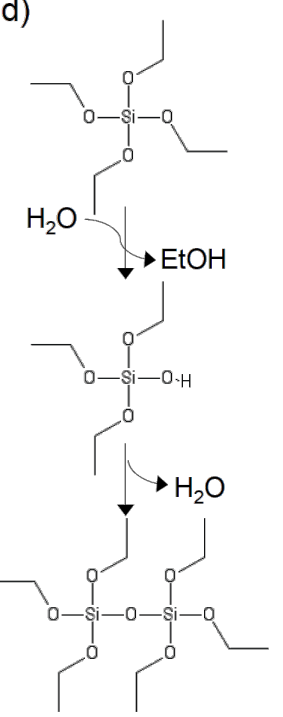

Figure 1: Schematic representation of the chemical modification and mineralization of tobacco mosaic virus (TMV) nucleoprotein nanotubes. (a) Genetically engineered virus particles with thousands of surface-exposed amino groups of lysine residues ( $T M V_{\text {Lys }}$ ) served as biotemplates for chemical conjugation reactions. (b) Hetero-bifunctional linker molecules (succinimidyl-( $N$-maleimidopropionamido) ester, SM(PEG) 4 ) were coupled to $\mathrm{TMV}_{\text {Lys }}$ via $\mathrm{N}$-hydroxysuccinimide (NHS) ester-mediated crosslinking with lysine primary amines, yielding amide bonds. (c) Mineralization-affecting peptides were conjugated to the maleimide-activated $\mathrm{SM}(\mathrm{PEG})_{4}$ linker portion via the sulfhydryl groups of their terminal cysteine residues, yielding stable thioether linkages. The resulting functionalized TMV templates fashioned with a dense peptide coating were (d) subjected to silica mineralization via hydrolysis and condensation of a tetraethoxysilane (TEOS) precursor in solution (mechanism indicated). 
structures $[34,65]$. These were laterally aligned or even starshaped [64] 3D arrays in many of the studies, reflecting and expanding the well-known capacities of these bio-nanorods to form various aggregates up to liquid-crystalline phases. In contrast, protocols resulting in nanoparticulate TMV-silica composites devoid of inorganic background granules and, moreover, with closed shells of well-adjustable thickness, are a matter of intense investigation. Such methods would enable the manufacture of novel TMV derivatives, further expanding their application potential to miniaturized arrays and devices [66-68] and "smart" functional materials [31,69] for numerous purposes. TMV-inorganic hybrids will likely yield rigid and durable [70] technical components, which are also compatible with biological molecules and activities [71].

To fabricate thick, continuous silica coatings (e.g., on immobilized TMV rods), polyaniline interlayers were employed to shield both charges and hydrophobic patches of the viral protein coating before subjecting it to TEOS-mediated mineralization [26]. A more refined and tighter control of the silica mineralization can be achieved by ordered, repetitive arrangements of differently charged protein domains and specific functional groups therein. This was demonstrated in vitro by help of various mineralization-inducing peptides $[55,56,61,72]$. Positively charged amino acid residues (Lys, Arg) in such peptides electrostatically interact with siloxane groups, while Ser, His and Asp may undergo hydrogen bonding or polar interactions with solute or nanosized colloidal mineral precursors [7,60,63,72-74]. Additionally, negatively charged amino acids that are present are supposed to have an enhancing effect on TEOS hydrolysis. This is especially true if they are closely adjacent to positive charges, where such combinations may act as charge-relay systems [61,75]. Effective peptides may resemble motifs found in natural silica biomineralization-directing proteins (in both their amino acid composition and sequence [58]), but may also comprise randomly assembled sequences resulting from mere in vitro library screening.
Since a growing body of experience with relatively diverse silicification-guiding peptides is available, we decided to install a number of distinct amino acid sequence types on structuredirecting TMV nanorods. This allows for the systematic investigation of their influence on silica coating reactions via ethanolcontaining TEOS on this viral backbone for the first time.

Genetically modified TMV particles $\left(\mathrm{TMV}_{\mathrm{Lys}}\right)$ with an accessible amino group on every CP subunit [76] were chemically equipped with a dense peptide coating via succinimidyl esteractivated, bifunctional, PEG-based linkers, and their subsequent maleimide-mediated conjugation to thiol groups of terminal cysteine residues present in every peptide. Five different peptide sequences were selected (see Table 1): (i) $(\mathrm{KD})_{5} \mathrm{C}$ and $(\mathrm{KD})_{10} \mathrm{C}$ with alternating amino and carboxyl functionalities (sequences KDKDKDKDKDC and KDKDKDKDKDKDKDKDKDKDC, respectively) on the basis of Kuno et al. [61]; (ii) $\mathrm{CA}_{4} \mathrm{H}_{4}$ (sequence CAAAAHHHH) according to Yuwono and Hartgerink [17], with two stretches of different amino acid residues arranged blockwise to expose a cluster of imidazole side chains; and (iii) 44C (HSSHHQPKGTNPC) and 31C (HHGHSPTSPQVRC), two ZnO-binding peptides isolated by phage display [60]. The distinct peptide-fashioned $\mathrm{TMV}_{\mathrm{Lys}}$ templates were incubated in TEOS precursor solution in parallel with linker-coated and plain $\mathrm{TMV}_{\mathrm{Lys}}$ controls (and in some tests wildtype $\mathrm{TMV}_{\mathrm{wt}}$ ) under equal conditions. The products were analyzed and compared to determine favorable TMV template-peptide combinations for specific silica mineralization.

\section{Results and Discussion Surface functionalization of $\mathrm{TMV}_{\mathrm{Lys}}$ templates by conjugation of mineralization- promoting peptides}

To nucleate and govern the deposition of silica shells, functionalized plant viral nanorod templates were generated by linkerassisted chemical conjugation of mineralization-active peptides

\begin{tabular}{|c|c|c|c|c|c|c|c|}
\hline \multirow[t]{2}{*}{ Name } & \multirow[t]{2}{*}{ Abbreviation } & \multirow[t]{2}{*}{ Sequence } & \multirow[t]{2}{*}{ aa } & \multirow[t]{2}{*}{$M_{\mathrm{w}}(\mathrm{g} / \mathrm{mol})$} & \multirow[t]{2}{*}{$\mathrm{pl}$} & \multicolumn{2}{|c|}{ Net charge at $\mathrm{pH}$} \\
\hline & & & & & & 8.0 & 5.5 \\
\hline$(\mathrm{KD})_{5} \mathrm{C}$ & KD5 & KDKDKDKDKDC & 11 & 1337.5 & 6.25 & -0.8 & 0.4 \\
\hline$(\mathrm{KD}){ }_{10} \mathrm{C}$ & KD10 & $(\mathrm{KDKDKDKDKD})_{2} \mathrm{C}$ & 21 & 2553.8 & 6.62 & -0.8 & 0.7 \\
\hline $\mathrm{CA}_{4} \mathrm{H}_{4}$ & $\mathrm{AH}$ & CAAААНHНH & 9 & 945.0 & 7.52 & -0.6 & 3.6 \\
\hline $44 \mathrm{C}$ & $44 \mathrm{C}$ & HSSHHQPKGTNPC & 13 & 1429.5 & 8.31 & 0.3 & 3.7 \\
\hline $31 \mathrm{C}$ & $31 \mathrm{C}$ & HHGHSPTSPQVRC & 13 & 1442.6 & 8.31 & 0.4 & 3.7 \\
\hline
\end{tabular}


to the outer surface of genetically modified $\mathrm{TMV}_{\mathrm{Lys}}$ particles from plants. Every $\mathrm{CP}_{\mathrm{Lys}}$ subunit provided a primary amine group of a lysine residue at the protein's $\mathrm{C}$ terminus. This resulted in $\approx 2130$ sites selectively accessible to NHS estermediated coupling reactions per rod [76]. These were equipped with hetero-bifunctional crosslinker molecules (succinimidyl( $N$-maleimidopropionamido)-tetraethylene glycol ester, $\left.\mathrm{SM}(\mathrm{PEG})_{4}\right)$ serving as spacers and adapters for mineralizationaffecting peptides. These were installed via maleimidemediated conjugation of the cysteine sulfhydryl groups of the peptides. The resulting five distinct types of $\mathrm{TMV}_{\text {Lys }}-\mathrm{PEG}$-peptide particles with their different $\mathrm{CP}$ derivatives are listed in Table 2, as well as the linker-fashioned and plain $\mathrm{TMV}_{\mathrm{Lys}}$ templates used as references. The abbreviation scheme used was the following: abbreviations underscore the relevant functionalities or amino acids exposed; therefore, $\mathrm{TMV}_{\mathrm{Lys}}$ is named TMV-Lys from now on. Covalent conjuga- tion of peptides was confirmed for both single CPs and intact TMV particles by denaturing and native gel electrophoresis, respectively. Peptide modification of CPs resulted in a band shift with respect to increasing molecular weight, as compared to nonmodified CP in denaturing sodium dodecyl sulphate polyacrylamide gel electrophoresis (SDS-PAGE) (Figure 2a). The efficiency of peptide conjugation was determined by the ratio of the band intensities of modified and nonmodified CPs after Coomassie Blue staining. The binding efficiencies to individual CP subunits were $\approx 60 \%$ for all investigated peptides, corresponding to about 1250 peptides exposed on every $300 \mathrm{~nm}$ rod. The molecular weights of the differently modified CPs were in good agreement with the values calculated for the distinct conjugates (Table 2).

The intact TMV particles were analyzed by native gel electrophoresis $(0.9 \%$ agarose in TBE buffer, $\mathrm{pH} 8.0$; Figure $2 \mathrm{~b})$.

Table 2: Composition of TMV derivatives used in this study. Calculated and measured molecular weight $\left(M_{\mathrm{w}}\right)$ of modified CP species were in good agreement.

\begin{tabular}{|c|c|c|c|c|c|c|}
\hline \multirow[t]{2}{*}{ TMV derivative } & \multirow{2}{*}{$\begin{array}{l}\text { Abbreviation } \\
\text { (TMV-) }\end{array}$} & \multicolumn{3}{|c|}{ Composition of TMV derivative } & \multirow{2}{*}{$\begin{array}{l}\text { Calculated } M_{\mathrm{w}} \text { of } \mathrm{CP} \\
\text { conjugate }(\mathrm{kDa})\end{array}$} & \multirow{2}{*}{$\begin{array}{l}\text { Measured } M_{\mathrm{w}} \text { of } C P \\
\text { conjugate }^{\mathrm{a}}(\mathrm{kDa})\end{array}$} \\
\hline & & TMV $_{\text {Lys }}$ & $\mathrm{SM}(\mathrm{PEG})_{4}$ & Peptide & & \\
\hline $\mathrm{TMV}_{\text {Lys }}-\mathrm{PEG}-(\mathrm{KD})_{5} \mathrm{C}$ & KD5 & + & + & $(\mathrm{KD})_{5} \mathrm{C}$ & 19.5 & 19.9 \\
\hline $\mathrm{TMV}_{\text {Lys }}-\mathrm{PEG}-(\mathrm{KD})_{10} \mathrm{C}$ & KD10 & + & + & $(\mathrm{KD})_{10} \mathrm{C}$ & 20.7 & 21.9 \\
\hline $\mathrm{TMV}_{\text {Lys }}-\mathrm{PEG}-\mathrm{CA}_{4} \mathrm{H}_{4}$ & $\mathrm{AH}$ & + & + & $\mathrm{CA}_{4} \mathrm{H}_{4}$ & 19.1 & 20.2 \\
\hline $\mathrm{TMV}_{\text {Lys }}-\mathrm{PEG}-44 \mathrm{C}$ & $44 \mathrm{C}$ & + & + & $44 \mathrm{C}$ & 19.6 & 20.4 \\
\hline TMV $_{\text {Lys }}-P E G-31 C$ & $31 \mathrm{C}$ & + & + & $31 \mathrm{C}$ & 19.6 & 20.9 \\
\hline TMV $_{\text {Lys }}-\mathrm{PEG}$ & PEG & + & + & - & 18.1 & 18.2 \\
\hline TMV $_{\text {Lys }}$ & Lys & + & - & - & 17.6 & 17.4 \\
\hline
\end{tabular}

aMeasured $M_{\mathrm{w}}$ values are derived from SDS-PAGE band analyses via retardation factor values determined by Image J software [78] and calibration curves obtained from $M_{\mathrm{w}}$ standards separated on the same gel.

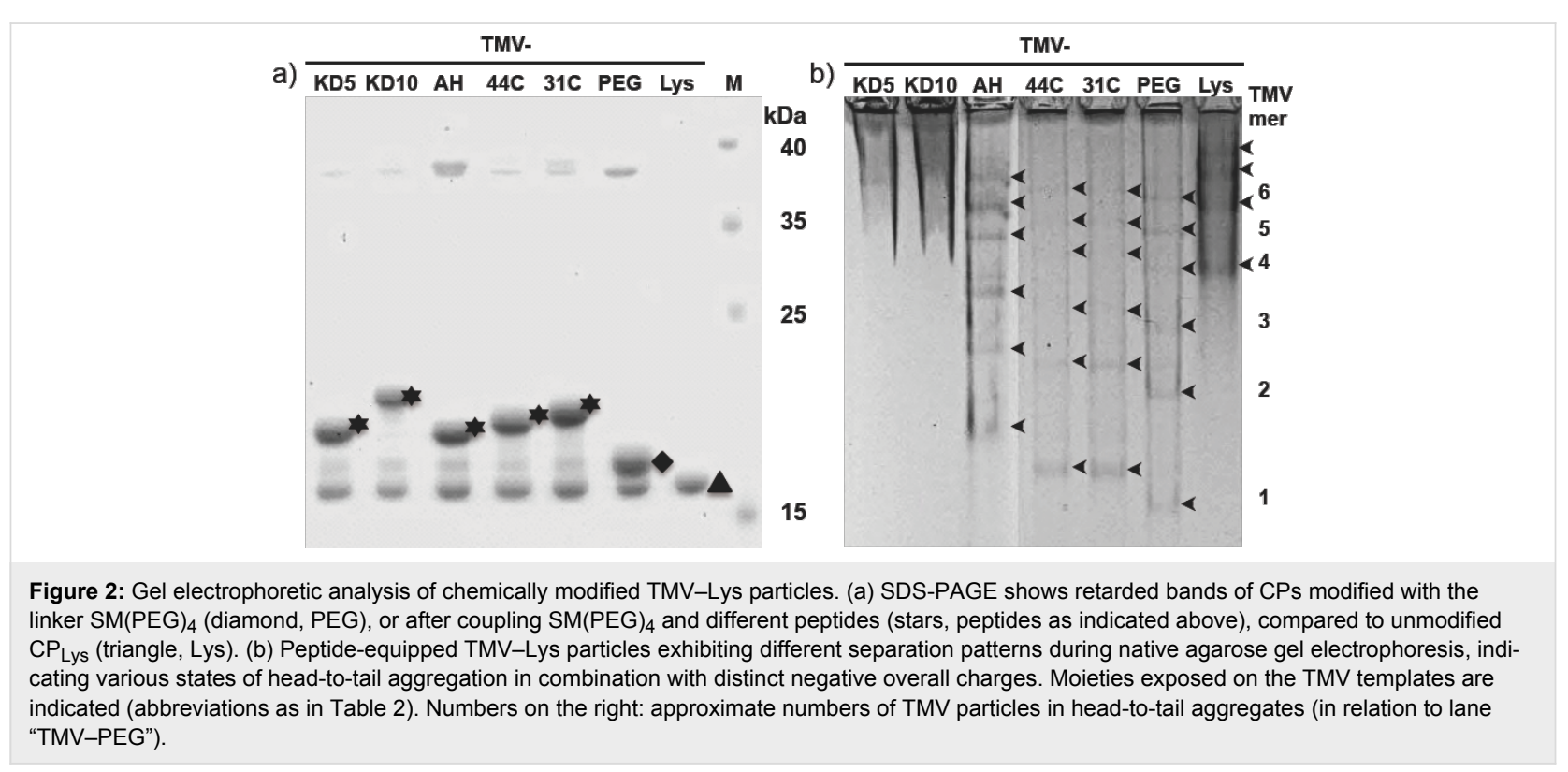


The linker coating of the control derivative $\mathrm{TMV}_{\mathrm{Lys}}-\mathrm{PEG}$ (TMV-PEG) exhibited an increase in negative net charge in comparison to TMV-Lys, resulting in a higher electrophoretic mobility. This effect was reduced by the conjugation of mineralization-affecting peptides: $\mathrm{TMV}_{\mathrm{Lys}}-\mathrm{PEG}-\mathrm{CA}_{4} \mathrm{H}_{4}$ (TMV-AH), TMV $\mathrm{Lys}_{\mathrm{s}}-\mathrm{PEG}-44 \mathrm{C}$ (TMV-44C) and $\mathrm{TMV}_{\mathrm{Lys}}-\mathrm{PEG}-31 \mathrm{C}$ (TMV-31C) exhibited retarded bands, which indicated the linkage of the peptides to the TMV-PEG template. TMV derivatives $\mathrm{TMV}_{\mathrm{Lys}}-\mathrm{PEG}-(\mathrm{KD})_{5} \mathrm{C}$ (TMV-KD5) and TMV $\mathrm{Lys}_{\mathrm{S}}-\mathrm{PEG}-(\mathrm{KD}){ }_{10} \mathrm{C}$ (TMV-KD10) could not be separated under the conditions applied: both samples did not migrate into the gel phase to a sufficient extent.

\section{Zeta potential measurement}

The zeta potentials (ZPs) of TMV-Lys nanorods and their derivatives were determined using a Malvern NanoSizer at a virus particle concentration of $0.5 \mathrm{mg} / \mathrm{mL}$ in ultrapure water $\left(\mathrm{ddH}_{2} \mathrm{O}\right)$ and in $30 \mathrm{mM}$ Tris- $\mathrm{HCl}$ buffer, $\mathrm{pH}$ 8.0, respectively (Figure 3). The ZPs measured in $\mathrm{ddH}_{2} \mathrm{O}$ were in general more negative ( $-28 \mathrm{mV}$ to $-78 \mathrm{mV}$ ) compared to those determined in buffer $(-10 \mathrm{mV}$ to $-25 \mathrm{mV})$, owing to the lower $\mathrm{pH}$ of $\approx 5.5$ of ultrapure water with $\mathrm{CO}_{2}$ dissolved in equilibrium with that in the air [79]. In addition, the increased electrolyte concentrations in the buffer lead to an enrichment of counter ions in the proximity of the TMV nanorods and thus a steeper decrease of the potential within a shorter distance from their surface (decrease of the Debye length). Therefore, ZP values measured in $\mathrm{ddH}_{2} \mathrm{O}$ are closer to the electric surface (Stern) potential of the particles [80].

The ZPs of the TMV derivatives (Figure 3) were correlated with the calculated isoelectric point ( $\mathrm{pI}$ ) of the conjugated peptides (see Table 1), and in most cases with the effective particle charges affecting their relative mobility in native agarose gel electrophoresis (see Figure 2b). Peptides $44 \mathrm{C}$ and $31 \mathrm{C}$ both are

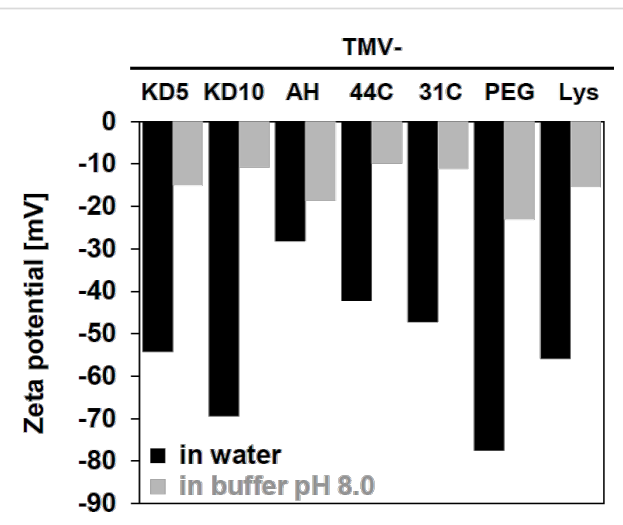

Figure 3: Zeta potential of bare and chemically modified TMV-Lys particles in $\mathrm{ddH}_{2} \mathrm{O}$ or $30 \mathrm{mM}$ Tris- $\mathrm{HCl} \mathrm{pH} \mathrm{8.0,} \mathrm{respectively} \mathrm{(modifica-}$ tions of TMV rods indicated above). predicted to exhibit moderate positive charges (of about 0.3 or 0.4 , respectively) at $\mathrm{pH} 8.0$, while peptides $\mathrm{AH}(-0.6), \mathrm{KD} 5$ and KD10 (both -0.8 ) are supposed to be negative. As coating of the TMV particles with maleimide-reactive $\mathrm{SM}(\mathrm{PEG})_{4}$ linker molecules devoid of peptides (TMV-PEG) introduced the most negative net charge (Figure 2b), all peptide-fashioned TMV derivatives had less negative ZPs compared to the linker-modified control (with about $-80 \mathrm{mV}$ in water and about $-25 \mathrm{mV}$ in buffer). While the ZP values of four products were largely in line with the calculated charges of the peptides (with TMV-44C and TMV-31C shifted to significantly less negative $Z P$ values compared to those of TMV-KD5 and -KD10), the absolute ZP determined for TMV-AH was shifted most extensively to more positive values, due to the contribution of the uncharged alanines (Figure 3). This reflects the sheath of tetrahistidine clusters exposed by the C-termini of peptide AH. Bare TMV-Lys templates with their plain protein coating exhibited ZP values close to those of TMV-KD5.

At high concentrations, TMV-AH aggregated into bundle-like structures in water but not in buffer. Such agglomerates could be separated by ultrasound; however, re-aggregation occurred after short time. 44C- or 31C-functionalized TMV formed raftlike aggregates in both water and buffer (as detected also after their mineralization, see SEM analysis below).

For inorganic particles, the physical stability of dispersions increases with the magnitude of the ZP. That is, highly negative or highly positive ZPs typically both result in stable suspensions $[81,82]$ due to Coulomb repulsion. The organic TMV template structures thus behaved analogously, with the agglomerating species $\mathrm{TMV}-\mathrm{AH},-44 \mathrm{C}$, and $-31 \mathrm{C}$ exhibiting the lowest ZP magnitudes in water. TMV-Lys with an absolute ZP value above 55 did not show aggregation at all.

\section{Mineralization of functionalized TMV templates}

The different TMV templates were subjected to silica deposition by dispersion in a buffer-free deposition solution of $\approx 11 \%$ (v/v) TEOS precursor solution in $\approx 45 \%$ (v/v) ethanol in ultrapure water (resulting in a $\mathrm{pH}$ of $\approx 5.5$ ) under agitation $(500 \mathrm{rpm})$ at $25{ }^{\circ} \mathrm{C}$ for up to twelve days in parallel experiments (see Experimental section). These conditions were adapted with respect to the ethanol concentration from an earlier comparative study on the mineralization capacities of distinct kinds of peptides [61]. The method was established in initial tests to achieve improved control over mineralization kinetics and product characteristics with peptide-equipped TMV templates. This is in comparison to protocols used for the TEOS-mediated silicification of bare $[21,34,64,65,83]$ or aniline-coated [26] TMV. Those protocols all employed reac- 
tion mixes of either alkaline or significantly lower $\mathrm{pH}$ (in most cases in buffer-free solutions) in variable ethanol concentrations and in one study supplemented by (3-aminopropyl)triethoxysilane (APTES) [64].

All TMV templates with absolute ZP magnitudes above $50 \mathrm{mV}$ showed a good dispersion in the mineralization solution, while TMV-AH, $-44 \mathrm{C}$ and $-31 \mathrm{C}$ did not form stable suspensions. At different reaction times, products were collected by centrifugation. After seven days of incubation, inorganic material sedimented from all reaction mixes, regardless of the presence or absence of TMV templates (Figure 4a). The precipitates were transparent in the presence of TMV-KD5, -PEG, and -Lys, as well as for the reference sample without template, whereas the sediments of TMV-KD10, $-\mathrm{AH},-44 \mathrm{C}$ and $-31 \mathrm{C}$ appeared milky white. In the absence of TMV, the reaction solution completely solidified, while all suspensions containing TMV templates remained liquid during the course of silica condensation (Figure 4a).

The morphology of TMV hybrid products subjected to mineralization for ten days was analyzed by transmission electron microscopy (TEM; see below, data not shown), and high resolution scanning electron microscopy (HRSEM; Figure 4b). A clear difference in the mineralization of functionalized and nonfunctionalized TMV templates was observed: Only nanorods presenting the silica-binding peptides KD5 or KD10 showed continuous inorganic surface coatings on every single particle, with no significant agglomeration of the virus hybrids. Furthermore, deposition on these templates was highly specific; only a low amount of non-bound silica particles had formed (Figure $4 \mathrm{~b}$ ). The templates TMV-AH, $-31 \mathrm{C}$, and $-44 \mathrm{C}$ induced silica deposition as well, but in contrast to TMV-KD5 and $-\mathrm{KD} 10$, the resulting composites did not contain separate rods anymore, but rather formed extended aggregates and bundles up to the $\mu \mathrm{m}$ size regime, especially pronounced for $-31 \mathrm{C}$ and $-44 \mathrm{C}$. TMV templates lacking specific effector peptides (i.e., TMV-PEG, TMV-Lys, $\mathrm{TMV}_{\mathrm{wt}}$ ) did not show any substantial inorganic coating at all, instead, some unspecific silica precipitation was observed (Figure 4b). It is known for in vitro systems that an alternating arrangement of lysine and aspartic acid residues (as in peptides KD5 and KD10) enhances dehydration of the TEOS precursor in the mineralization solution, in direct comparison to blockwise arrangements of the same amino acids. This results from an increased number of active sites for charge-relay effects [61]. The results of our comparative tests showing superior capacities of KD5 and KD10 to induce local silicification are in line with these earlier observations. This illustrates the beneficial effect of amino acid-based charge relay on a spatially directed TEOS conversion. Silica precipitation by sol-gel reaction from precursor solutions is likely to involve a gradual growth of individual silica nucleation cores rather than single or few specific phase transformations [74]. Hence, high surface densities of cooperating starter sites (such as repetitive KD pairs) may provide the best chance for an even growth of mineral shells, which are induced simultaneously at numerous closely adjacent sites.

The other peptides explored in this study, AH, 31C and 44C, all contain histidine residues as potential mineralization effectors. Their imidazole rings can catalyze hydrolysis of the TEOS precursor, resulting in deprotonated, negatively charged silicic acid, which then accumulates in the vicinity of the positively charged amino acids to facilitate silica mineralization [17]. The good efficiency of AH in promoting silica sheath formation from TEOS in the context of amphiphilic peptide fibers has been demonstrated [17]. 31C and 44C had not been tested with TEOS before, as they were originally identified due to their $\mathrm{ZnO}$ binding properties (data not shown) [60]. The agglomeration and bundle formation we found for all three respective mineralized TMV templates might be due to their aggregation before the mineralization process, as it is known for histidinepresenting TMV particles $[51,84,85]$. This is also indicated by their absolute $\mathrm{ZP}$ values of $<50 \mathrm{mV}$ measured in this study.

Most of the silicification-active peptides that convey the dehydration of precursor molecules such as TEOS [55,56,73,86,87] contain disproportionate amounts of positively charged amino acid residues (lysine, arginine or histidine). This reflects the design of silaffin, a natural silica-mineralizing protein rich in lysine and arginine residues [58,88]. Therefore, we speculated that bare TMV-Lys templates could also support the formation of silica shells in TEOS solution. The effect could be greater since the viral CPs are known to be N-terminally acetylated [89] and thereby might act as repetitive charge-relay systems on the viral surface. However, we could not detect any silica coating on TMV-Lys templates under the conditions applied. This may be due to the surrounding amino acids in the $\mathrm{CP}$ environment, which might slow down or even inhibit putative mineralizationsupporting activity of the lysine moiety of the CP.

$\mathrm{TMV}_{\mathrm{wt}}$ was also not mineralized in this experimental setup to an electron-optically detectable extent. This is in contrast to the strong and much faster mineralization of $\mathrm{TMV}_{\mathrm{wt}}$ particles from TEOS solution in alkaline or more acidic $\mathrm{pH}$ regimes, as performed in other labs and described above.

TEM analyses of the mineralized products confirmed the findings for the distinct TMV templates (not shown), with TMV-KD10-silica composites showing the strongest and most homogeneous contrast of otherwise non-stained samples. This template was therefore selected for a twelve day time course 

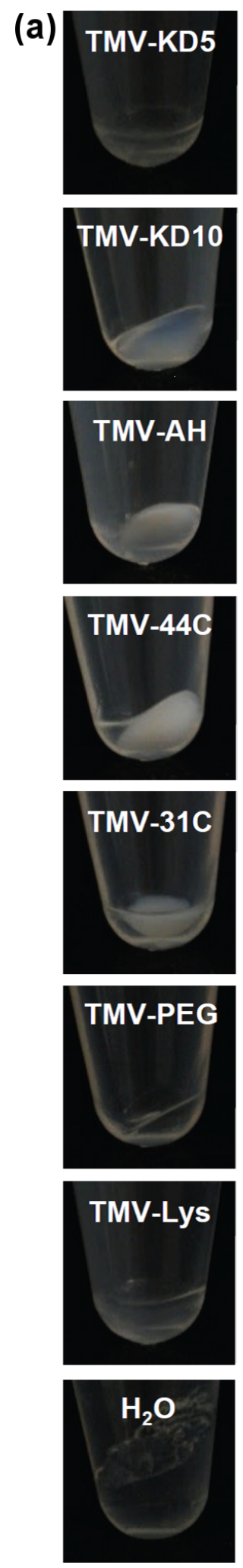
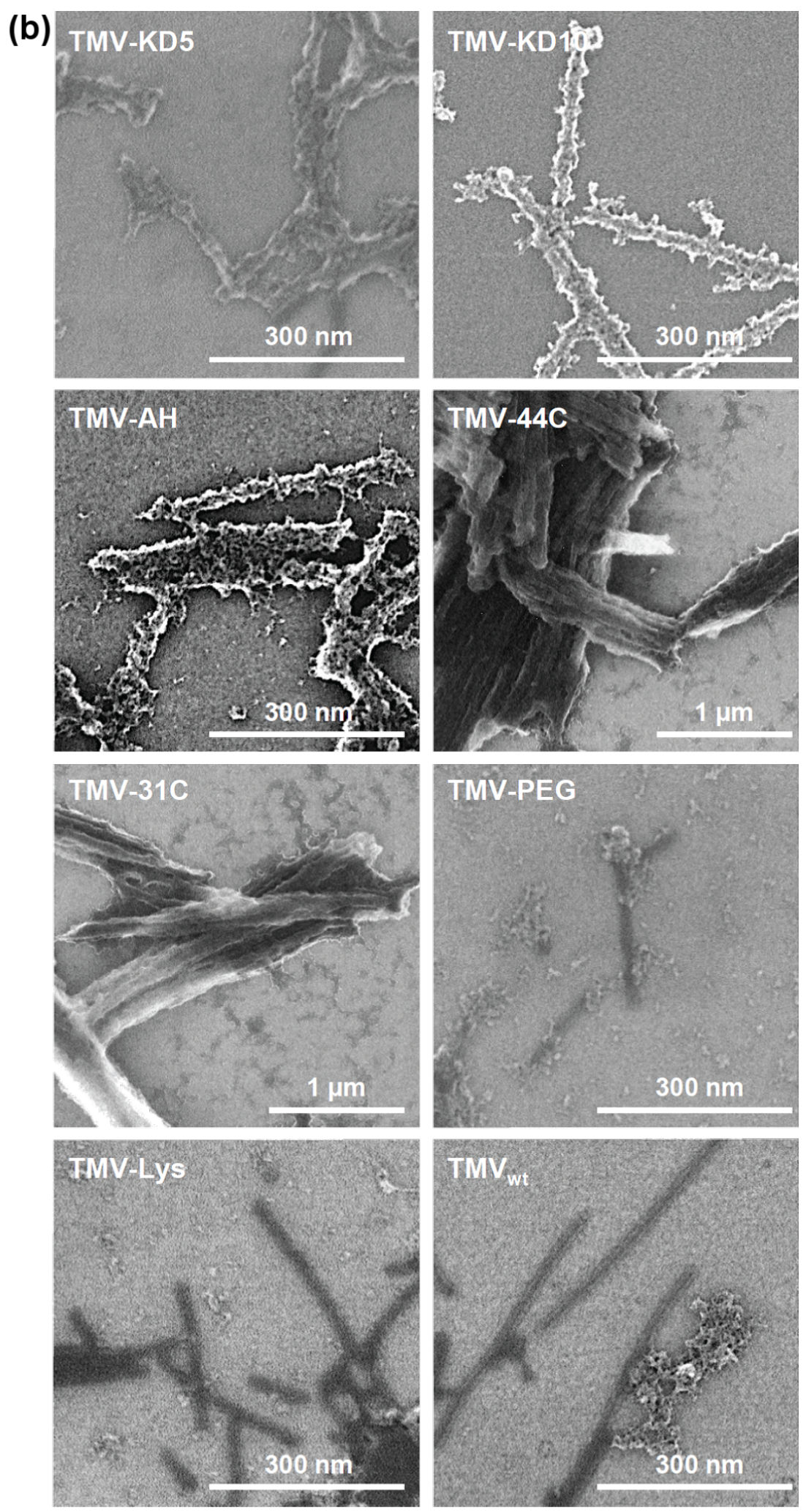

Figure 4: $\mathrm{SiO}_{2}$ deposition reactions using functionalized and non-modified TMV templates, as indicated. (a) Images of sedimented products, and (b) corresponding SEM analysis. TMV-Lys-template (or water control) solutions were mixed with absolute EtOH (99.9\%) and TEOS in a 4:4:1 volume ratio. Reaction products were sedimented by centrifugation (after 7 days of incubation in (a) or 10 days in (b)), resuspended in ddH $\mathrm{H}_{2} \mathrm{O}$ and prepared for SEM (for details, refer to text). 
experiment to investigate the growth kinetics of its mineral shells, and if the thickness of the silica coating might be controlled via the TEOS incubation time. Total widths of randomly selected, low-contrast TMV-KD10 cores surrounded by electron-dense sheaths were measured in digital TEM images by help of image processing software from the fifth day onwards. This revealed an increase of layer thickness with progressing time (Figure 5). After ten days of reaction time, the TMV-silica hybrids exhibited average diameters of about $29 \pm 2 \mathrm{~nm}$, which did not further increase upon extended incubation. At the same time, granular $\mathrm{SiO}_{2}$ deposits began to differentiate on the nanotube surfaces, rendering them less smooth than during earlier stages. The overall diameter, that is, the height of TMV-KD10-templated hybrid rods, after ten days of mineralization was additionally measured by AFM (data not shown). For this purpose, mineralized viruses were deposited on a silicon substrate. The average of the resulting mean values of the virus height was in good agreement with the TEM data and revealed a typical particle diameter of $30 \mathrm{~nm}$, corresponding to $\mathrm{a} \approx 6 \mathrm{~nm}$ linker-peptide-silica coating of the $18 \mathrm{~nm}$ TMV core. Different from non-modified viral rods immobilized on a silicon substrate, where reduction of the virus height due to attraction to the substrate surface is observed [32], the adhesion of mineralized viruses from suspensions to the wafer substrates did not reduce the objects' height. This indicated the formation of a rigid composite not radially compressed upon its surface adsorption.

\section{ToF-SIMS analysis of the deposited material}

An analysis of the deposited materials with time-of-flight secondary ion mass spectrometry (ToF-SIMS) [90] was performed on air-dried, drop cast suspensions of $\mathrm{TMV}_{\mathrm{wt}}$ or $\mathrm{TMV}-\mathrm{KD} 10$ particles (both with and without 10 days of exposure to TEOS). Positive and negative secondary ion spectra were recorded from random positions of the TMV deposits. The peak assignment is based on high mass resolution data and isotope patterns for Si. As shown in Figure 6, the intensity of the $\mathrm{Si}^{+}$signal decreases substantially from TMV-KD10 particles incubated with TEOS (blue) to the $\mathrm{TMV}_{\mathrm{wt}}$ control with TEOS (red) to both negative controls not incubated in TEOS solutions (green and purple). Analyzing $\mathrm{SiOH}^{+}$and several fragments characteristic of silica in negative polarity spectra $\left(\mathrm{SiO}_{2}{ }^{-}, \mathrm{SiO}_{3}{ }^{-}, \mathrm{SiO}_{3} \mathrm{H}^{-}\right)$indicated

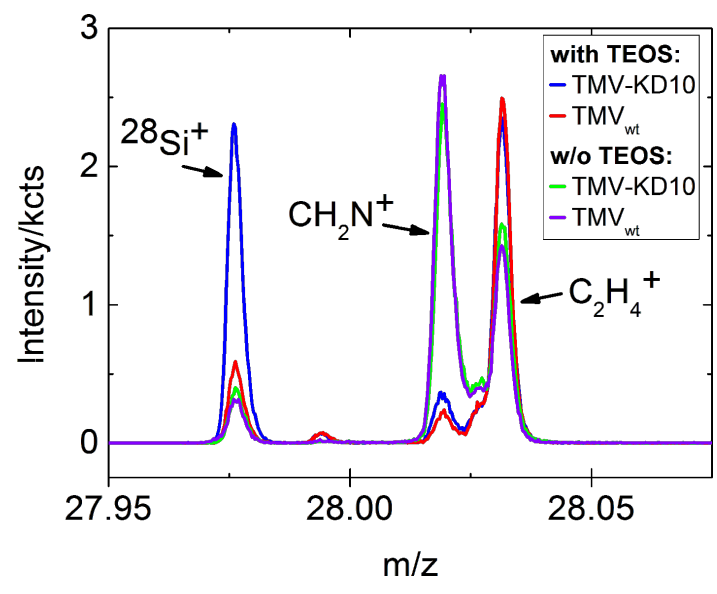

Figure 6: ToF-SIMS analysis for determination of silica deposition. TMV-KD10 with TEOS (blue) and without TEOS (green), TMV wt $_{\text {with }}$ TEOS (red) and without TEOS (purple) after ten days of incubation. The peak at $m / z 27.97$ indicates $\mathrm{Si}$, the peak at $\mathrm{m} / \mathrm{z} 28.02 \mathrm{CH}_{2} \mathrm{~N}^{+}$, and the peak at $\mathrm{m} / \mathrm{z} 28.03 \mathrm{C}_{2} \mathrm{H}_{4}{ }^{+}$. For TMV-KD10 with TEOS and $\mathrm{TMV}_{\text {wt }}$ with TEOS, the decrease of the $\mathrm{CH}_{2} \mathrm{~N}^{+}$peak, indicating peptide/protein components, is an indirect effect of the mineralization, shielding the soft-matter surface of biotemplate particles.

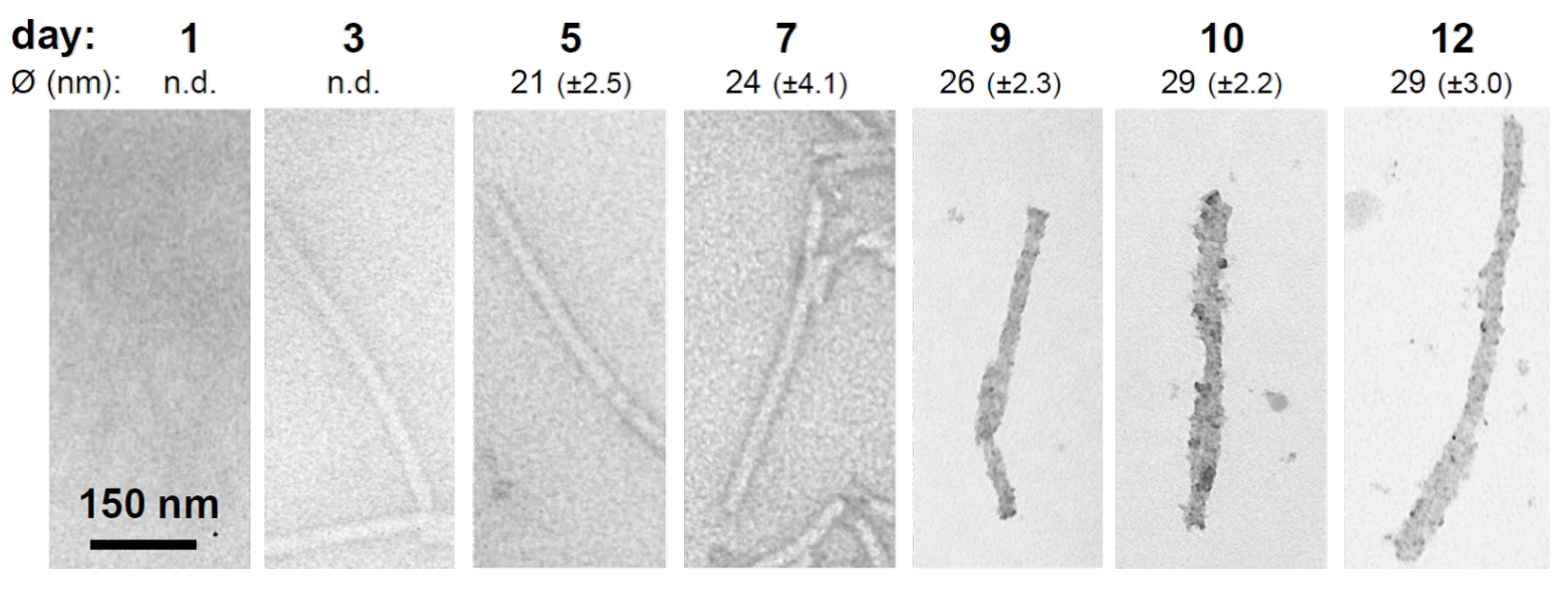

Figure 5: Time-resolved monitoring of silica shell growth on TMV-KD10 templates: TEM analysis of non-stained specimens, after the reaction times indicated above. Total average diameters $(\varnothing \pm$ standard deviations) of mineralized TMV-KD10-hybrids were determined from 11-15 randomly selected nanorod products collected between one and twelve days of incubation. 
the same trend. Since the sample preparation method did not yield fully TMV-covered samples, the recorded mass spectra averaged over a field of view of $500 \times 500 \mu \mathrm{m}^{2}$ show individual levels of $\mathrm{Au}^{-}$stemming from the underlying substrate. In order to correct for this dispersion or area effect, the raw intensities of $\mathrm{Si}^{+}$and $\mathrm{SiOH}^{+}$were normalized according to the gold signals of each analyzed spot. Semi-quantitative silicification levels obtained thereof are presented in Table 3.

Table 3: Relative silicification levels determined from normalized $\mathrm{Si}^{+}$ and $\mathrm{SiOH}^{+}$intensities in SIMS. TEOS exposure 10 days, when applicable.

\begin{tabular}{lll} 
Construct & $\begin{array}{l}\text { Normalized } \\
\mathrm{Si}^{+}\end{array}$ & $\begin{array}{l}\text { Normalized } \\
\mathrm{SiOH}^{+}\end{array}$ \\
\hline TMV-KD10 with TEOS & $100 \%$ & $100 \%$ \\
TMV $_{\text {wt }}$ with TEOS & $18 \%$ & $17 \%$ \\
TMV-KD10 without TEOS & $1 \%$ & $1 \%$ \\
TMV $_{\text {wt }}$ without TEOS & $<1 \%$ & $<1 \%$ \\
& & \\
\hline
\end{tabular}

As shown in Table 3, the normalized intensities of two silicaderived fragments obtained with SIMS allow for a rough but reasonable quantification of the conversion of TEOS to silica induced by bare and KD10-functionalized TMV particles. While all negative controls not exposed to TEOS show negligible levels of $\mathrm{Si}^{+}$and $\mathrm{SiOH}^{+}$, both TMV-KD10 and $\mathrm{TMV}_{\mathrm{wt}}$ exposed to TEOS did form insoluble silica to considerably different extents. This resulted in about five times higher amounts of mineral on the peptide-modified virus. This finding is in agreement with our microscopic observations, which were not sufficient to resolve the deposition of silica on the wild type viral template. The ToF-SIMS analysis therefore revealed either a spontaneous hydrolysis of TEOS (also occurring in the absence of effector peptides) or a low but specific mineralization-promoting activity of the bare viral CP surface (not detectable by electron-optical imaging). The low SIMS $\mathrm{Si}^{+}$and $\mathrm{SiOH}^{+}$signal intensities, and the necessary high mass resolution for unambiguous fragment assignments, precluded SIMS imaging with high lateral resolution. Hence, the obtained SIMS data cannot visualize mineralized individual TMV particles or distinguish between silica bound to virus particles and silica deposited by self-hydrolysis.

\section{Conclusion}

A systematic comparison of TMV-based nanobiotemplates chemically functionalized with different types of mineralization-affecting peptides revealed superior capacities of repetitive, alternating KD sequences in guiding the deposition of silica sheaths from TEOS precursor solutions around the viral softmatter cores. The peptide KD10 designed in this study on the basis of earlier tests [61] allowed for the most selective and controllable silicification by sol-gel condensation. This was likely due to its charge-relay activity, in comparison to different histidine-containing effector peptides and the bare or linkercoated viral scaffold surface. To our knowledge, this is the first evaluation of peptide-equipped TMV templates with regard to the generation of silica nanostructures of adjustable diameter. The previous studies of other researchers, all of which employed natural or aniline-modified TMV to nucleate silica deposition (as specified above), yielded either nanometric coatings of individual particles, or differently organized bio-inorganic mesostructures, but did not focus on fine-tuning the growth of the silica shells on the one-to-ten nm range. This was intended here and best achieved by the KD10-exposing TMV variant, for which a convincing correlation between silicification time and mineral layer thickness could be demonstrated.

The KD10-fashioned plant viruses thus enable the one-pot manufacture of freely suspended silica nanorods with a softmatter core, devoid of significant amounts of byproducts. It would be interesting to characterize the mechanical properties of these composites in comparison to synthetically synthesized silica nanorods. This could potentially lead to fundamentally novel types of fiber-reinforced biohybrid materials. Furthermore, the method may also give rise to an efficient fabrication of rigid, ultrasmall components of unusual shapes, on the basis of different nonlinear kinked and branched TMV-based architectures generated recently in our lab [54].

Finally, peptides spatially immobilized in a selective manner on certain target sites of biotemplates might also be a clue to the use of silica deposition as a "bionic glue". On appropriate TMV variants, specific coupling groups of amino acids are confined to outer, inner or end surfaces of the nucleoprotein tubes, respectively. Serial in vitro assembly of different genetically engineered CP types on RNA scaffolds can even generate nanorod subdomains, offering unique coupling functionality [76]. Addressing such sites for a selective conjugation of mineralization-guiding peptides such as KD10 might pave future routes towards a firm and controlled integration of TMV-based nanostructures into miniaturized devices. Here they might act, for example, as adaptor templates, enabling an ultradense presentation of functional molecules on the non-mineralized regions of their multivalent protein surfaces.

Taken together, extended composite bio-hybrid materials and complex miniaturized systems both might profit from the precise shapes, high availabilities and immense in vitro tuning potential of plant viral templates, and their peptide-controlled transformation into mineralized nanostructured composites adapted to specific future applications. 


\section{Experimental Materials}

The peptides, $(\mathrm{KD})_{5} \mathrm{C},(\mathrm{KD}){ }_{10} \mathrm{C}$, and $\mathrm{CA}_{4} \mathrm{H}_{4}$, of $90 \%$ purity were provided by GeneCust (Dudelange, Luxembourg). Peptides $31 \mathrm{C}$ and $44 \mathrm{C}$ were purchased from EMC Microcollections (Tübingen, Germany).

\section{TMV functionalization with bifunctional linker molecules and peptides}

Wild type $\mathrm{TMV}_{\mathrm{wt}}$ and genetically modified $\mathrm{TMV}_{\text {Lys }}[76]$ (also named TMV-Lys here to underscore the functional amino groups exposed by its lysine side chains) were purified according to Gooding and Hebert [91]. Peptide conjugation onto the virus surface followed a protocol established on the basis of literature data $[92,93]$ and instruction kindly provided by Sourabh Shukla and Nicole Steinmetz, Case Western Reserve University, Cleveland, Ohio, U.S.A. For this procedure, $1200 \mu \mathrm{L}$ of TMV-Lys particles $(5 \mathrm{mg} / \mathrm{mL})$ in $10 \mathrm{mM}$ sodium potassium phosphate (SPP) pH 7.2 were mixed with $9 \mu \mathrm{L}$ of $1 \mathrm{M}$ hetero-bifunctional crosslinker, succinimidyl- $(N$ maleimidopropionamido)-tetraethylene glycol ester (SM(PEG) 4 , Thermo Scientific, Karlsruhe, Germany) dissolved in dimethyl sulfoxide and incubated at $37{ }^{\circ} \mathrm{C}$ for $2 \mathrm{~h}$ under agitation (horizontal shaking at $500 \mathrm{rpm}$ ). The TMV particles were sedimented for $1.5 \mathrm{~h}$ at $90,500 \mathrm{~g}$ and $4{ }^{\circ} \mathrm{C}$ in an Optima L-90K ultracentrifuge (Beckman Coulter, Krefeld, Germany). The resulting pellet of linker-equipped TMV (named TMV-PEG) was resuspended in $600 \mu \mathrm{L}$ of $10 \mathrm{mM} \mathrm{SPP} \mathrm{pH} \mathrm{7.2.}$ A volume of $100 \mu \mathrm{L}$ of TMV-PEG solution was mixed with $800 \mu \mathrm{L}$ of $10 \mathrm{mM} \mathrm{SPP} \mathrm{pH} 7.2$ and $40 \mu \mathrm{L}$ of peptides $(3.3 \mathrm{mg} /$ $\mathrm{mL}$ ) dissolved in dimethylformamide and incubated at $30{ }^{\circ} \mathrm{C}$ for $2 \mathrm{~h}$ and subsequently at $4{ }^{\circ} \mathrm{C}$ overnight under agitation as above. The TMV particles with conjugated peptides were sedimented by ultracentrifugation as above. The pellets were washed with $1 \mathrm{~mL}$ of ultrapure water $\left(\mathrm{ddH}_{2} \mathrm{O}, 18.3 \mathrm{M} \Omega \mathrm{cm}\right.$, purified by a membraPure system, Aquintus, Bodenheim, Germany) and resuspended in $100 \mu \mathrm{L}$ of $\mathrm{ddH}_{2} \mathrm{O}$. The $\mathrm{TMV}_{\mathrm{wt}}$ and TMV-Lys concentrations were determined by UV spectroscopy with a NanoDrop ND-1000 spectrophotometer (PeqLab, Erlangen, Germany) at a wavelength of $260 \mathrm{~nm}$, using the extinction coefficient of TMV particles $\left(3 \mathrm{~mL} \mathrm{mg}^{-1} \mathrm{~cm}^{-1}\right.$ [94]). For estimating concentrations of the different biotemplate rods, the band intensities of modified $\mathrm{CPs}$ and unmodified $\mathrm{CP}_{\mathrm{Lys}}$ after SDS-PAGE separation and Comassie Blue staining were compared (see below).

\section{Electrophoretic analysis}

The modified CPs were analyzed by denaturing SDS-PAGE [95]. Samples containing $0.2 \mu \mathrm{g}$ of protein were heated for $5 \mathrm{~min}$ at $95{ }^{\circ} \mathrm{C}$ in sample buffer $(50 \mathrm{mM}$ Tris- $\mathrm{HCl}$ (tris(hydroxymethyl)aminomethan hydrochloride) $\mathrm{pH} 6.8$,
$2 \%(\mathrm{w} / \mathrm{v}) \mathrm{SDS}, 0.1 \%(\mathrm{w} / \mathrm{v})$ bromophenol blue, $10 \%$ glycerol, $100 \mathrm{mM}$ dithiothreitol) and separated on 15\% PA gels. Fixed gels were stained with Coomassie Brilliant Blue R250 (Serva Electrophoresis, Heidelberg, Germany) according to standard procedures [96].

Modified and unmodified TMV-Lys templates were separated as intact particles in native $0.9 \%$ agarose gels in $98 \mathrm{mM}$ Tris $\mathrm{pH} 8.0,89 \mathrm{mM}$ boric acid, $2 \mathrm{mM}$ EDTA. $12 \mu \mathrm{g}$ of total protein in sample buffer (10 mM SPP pH 7.2, 0.1\% (w/v) bromophenol blue, $10 \%$ glycerol) were applied per lane. TMV bands were stained with Coomassie Brilliant Blue R250.

\section{Zeta potential determination and charge calculation}

The zeta potential was measured with a Malvern Zetasizer Nano ZS (Malvern Instruments, Worcestershire, UK) using disposable folded cuvettes. The Smoluchowski approximation was used according to instrument settings to convert the electrophoretic mobility to a zeta potential. The experiments consisted of 30 runs per measurement. All experiments were conducted in triplicate. The zeta potential was measured for each sample with a concentration of $0.5 \mathrm{mg} / \mathrm{mL}$ TMV particles solution in $\mathrm{ddH}_{2} \mathrm{O}(\mathrm{pH} 5.5)$ as well as in $30 \mathrm{mM}$ Tris- $\mathrm{HCl}$ at $\mathrm{pH}$ 8.0.

\section{TMV particle mineralization}

Peptide-functionalized TMV templates resuspended in water (see above) were kept for one to two days at $4{ }^{\circ} \mathrm{C}$ to allow their complete dispersion after ultracentrifugation. For the mineralization of particles with and without linkers and conjugated peptides, a $40 \mu \mathrm{L}$ TMV template solution $(10 \mathrm{mg} / \mathrm{mL})$ was mixed with $50 \mu \mathrm{L} 20 \%(\mathrm{v} / \mathrm{v})$ TEOS (Sigma-Aldrich, München, Germany) in ethanol (99.8\% p.a.), resulting in final concentrations in the mineralization reaction mixture of $4.4 \mathrm{mg} / \mathrm{mL}$ TMV, $11.1 \%$ (v/v) TEOS, and 44.4\% (v/v) ethanol in an aqueous solution of $\mathrm{pH} 5.5-5.6$. It was crucial to mix TEOS and ethanol before combining it with TMV particles in order to preserve their structural integrity. Mineralization reactions were incubated for $1,2,5,7,10$ or 12 days under agitation (horizontal shaking at $500 \mathrm{rpm}$ ) at $25{ }^{\circ} \mathrm{C}$. The reaction mixture was precipitated in a table centrifuge for $15 \mathrm{~min}$ at $20,000 \mathrm{~g}$ and $18{ }^{\circ} \mathrm{C}$. The supernatant was discarded and the pellet washed twice with $200 \mu \mathrm{L}$ of $50 \%(\mathrm{v} / \mathrm{v})$ ethanol to remove residual unconverted TEOS. The pellet was resuspended in $50 \mu \mathrm{L}$ of $\mathrm{ddH}_{2} \mathrm{O}$ and centrifuged for $30 \mathrm{~min}$ at $10,000 \mathrm{~g}$. The resulting pellet was dissolved in $50 \mu \mathrm{L}$ of ultrapure water.

\section{Characterization of mineralized TMV particles}

The surface of mineralized TMV particles was characterized by SEM analysis. $20 \mu \mathrm{L}$ of 1:250 diluted, mineralized TMV solutions in ultrapure water (for the mineralized TMV particle solu- 
tion preparation see the previous section) were pipetted on n-Si wafer substrates and air dried. The samples were analyzed in an ultrahigh resolution field emission SEM (FE-SEM; S-5200, Hitachi Ltd., Tokyo, Japan) at $30 \mathrm{kV}$.

The TEM analysis was carried out to determine the silica shell thickness of TMV-KD10 particles after different reaction times. $3 \mu \mathrm{L}$ of mineralized TMV particles in solution were incubated on a 400-mesh formvar, carbon-covered copper grid for $5 \mathrm{~min}$. The droplet was removed with five droplets of ultrapure water and air dried. The samples were analyzed under a Zeiss EM-10A TEM (Carl Zeiss, Oberkochen, Germany) at $60 \mathrm{kV}$.

For ToF-SIMS analysis, Si chips $(5 \times 10 \mathrm{~mm})$ were cut from n-Si wafers (CrysTec, Berlin, Germany) and used as supporting substrates. These were coated with a $4 \mathrm{~nm}$ thick chromium layer for adhesion and a $30 \mathrm{~nm}$ thick gold layer by physical vapor deposition (PVD; Varian NRC 836, Palo Alto, California, U.S.A.). All samples used for mineralization analysis were found to be free of $\mathrm{Si}$ and silicon oil contamination, which could potentially interfere with the analysis.

$10 \mu \mathrm{L}$ of a 1:250 diluted solution of mineralized TMV or control preparations in ultrapure water (see TMV particle mineralization) were pipetted on a gold-covered n-Si wafer and air dried. ToF-SIMS was performed on a TOF.SIMS5 instrument (ION-TOF GmbH, Münster, Germany). The spectrometer was equipped with a Bi cluster primary ion source and a reflection-type time-of-flight analyzer. The UHV base pressure was $<5 \times 10^{-9}$ mbar. For high mass resolution, the Bi source was operated in the "high current bunched" mode, providing short $\mathrm{Bi}_{1}{ }^{+}$primary ion pulses at $25 \mathrm{keV}$ energy and a lateral resolution of approximately $4 \mu \mathrm{m}$. The short pulse length of 0.6 to $1.0 \mathrm{~ns}$ allowed for high mass resolution. The primary ion beam was rastered across a $500 \times 500 \mu \mathrm{m}^{2}$ field of view on the sample, and $128 \times 128$ data points were recorded. Primary ion doses were kept below $10^{11}$ ions $/ \mathrm{cm}^{2}$ (static SIMS limit). The spectra were calibrated against $\mathrm{C}^{-}, \mathrm{CH}^{-}, \mathrm{CH}_{2}^{-}$, and $\mathrm{Au}^{-}$, or on the $\mathrm{C}^{+}, \mathrm{CH}^{+}, \mathrm{CH}_{2}{ }^{+}$, and $\mathrm{CH}_{3}{ }^{+}$peaks, respectively. Based on these datasets, the chemical assignments for characteristic fragments were determined.

\section{Acknowledgements}

The authors are grateful to Diether Gotthardt and Sigi Kober for gardening and technical assistance at the University of Stuttgart, and to Sourabh Shukla and Nicole Steinmetz, Case Western Reserve University, Cleveland, Ohio, U.S.A., for sharing laboratory instructions with us. Many thanks go to the DFG (SPP1569 and PAK415) for funding, and the Carl-ZeissStiftung for additional financial support via the Projekthaus NanoBioMater at the University of Stuttgart.

\section{References}

1. Leblanc, J. L. Prog. Polym. Sci. 2002, 27, 627-687. doi:10.1016/S0079-6700(01)00040-5

2. Bouwmeester, H.; Brandhoff, P.; Marvin, H. J. P.; Weigel, S.; Peters, R. J. B. Trends Food Sci. Technol. 2014, 40, 200-210. doi:10.1016/j.tifs.2014.08.009

3. Stark, W. J.; Stoessel, P. R.; Wohlleben, W.; Hafner, A. Chem. Soc. Rev. 2015, in press. doi:10.1039/c4cs00362d

4. Henstock, J. R.; Canham, L. T.; Anderson, S. I. Acta Biomater. 2015, 11, 17-26. doi:10.1016/j.actbio.2014.09.025

5. Vallet-Regí, M.; Ruiz-Hernández, E. Adv. Mater. 2011, 23, 5177-5218. doi:10.1002/adma.201101586

6. Tang, F.; Li, L.; Chen, D. Adv. Mater. 2012, 24, 1504-1534. doi:10.1002/adma.201104763

7. Yildirim, A.; Acar, H.; Erkal, T. S.; Bayindir, M.; Guler, M. O. ACS Appl. Mater. Interfaces 2011, 3, 4159-4164. doi:10.1021/am201024w

8. Yang, X.; Tang, H.; Cao, K.; Song, H.; Sheng, W.; Wu, Q. J. Mater. Chem. 2011, 21, 6122-6135. doi:10.1039/c0jm04516k

9. Mann, S. Nat. Mater. 2009, 8, 781-792. doi:10.1038/nmat2496

10. Paris, O.; Burgert, I.; Fratzl, P. MRS Bull. 2010, 35, 219-225. doi:10.1557/mrs2010.655

11. Zollfrank, C.; Scheibel, T.; Seitz, H.; Travitzky, N. Bioinspired Materials Engineering. Ullmann's Encyclopedia of Industrial Chemistry; Wiley-VCH Verlag GmbH \& Co. KGaA: Weinheim, Germany, 2014; pp 1-22. doi:10.1002/14356007.s04_s01

12. Mann, S. Mineralization in biological systems. Inorganic Elements in Biochemistry; Structure and Bonding, Vol. 54; Springer: Berlin, Germany, 1983; pp 125-174. doi:10.1007/BFb0111320

13. Weiner, S.; Dove, P. M. Rev. Mineral. Geochem. 2003, 54, 1-29. doi:10.2113/0540001

14. Wu, Z. J.; Xiang, H.; Kim, T.; Chun, M.-S.; Lee, K. J. Colloid Interface Sci. 2006, 304, 119-124. doi:10.1016/j.jcis.2006.08.055

15. Cademartiri, R.; Brook, M. A.; Pelton, R.; Brennan, J. D. J. Mater. Chem. 2009, 19, 1583-1592. doi:10.1039/b815447c

16. Aljabali, A. A. A.; Shah, S. N.; Evans-Gowing, R.; Lomonossoff, G. P.; Evans, D. J. Integr. Biol. 2011, 3, 119-125. doi:10.1039/C0IB00056F

17. Yuwono, V. M.; Hartgerink, J. D. Langmuir 2007, 23, 5033-5038. doi:10.1021/la0629835

18. Bittner, A. M.; Alonso, J. M.; Górzny, M. Ł.; Wege, C. Nanoscale Science and Technology with Plant Viruses and Bacteriophages. In Structure and physics of viruses: An integrated textbook; Mateu, M. G., Ed.; Subcellular Biochemistry, Vol. 68; Springer Netherlands: Dordrecht, Netherlands, 2013; pp 667-702. doi:10.1007/978-94-007-6552-8_22

19. Mao, C.; Liu, A.; Cao, B. Angew. Chem., Int. Ed. 2009, 48, 6790-6810. doi:10.1002/anie.200900231

20. Lomonossoff, G. P.; Evans, D. J. Applications of Plant Viruses in Bionanotechnology. In Plant Viral Vectors; Palmer, K.; Gleba, Y., Eds.; Current Topics in Microbiology and Immunology, Vol. 375; Springer: Berlin, Germany, 2014; pp 61-87. doi:10.1007/82_2011_184

21. Shenton, W.; Douglas, T.; Young, M.; Stubbs, G.; Mann, S. Adv. Mater. 1999, 11, 253-256. doi:10.1002/(SICI)1521-4095(199903)11:3<253::AID-ADMA253>3.0.C $0 ; 2-7$

22. Pouget, E.; Grelet, E. Langmuir 2013, 29, 8010-8016. doi:10.1021/la401170m

23. Yang, S. H.; Chung, W.-J.; McFarland, S.; Lee, S.-W. Chem. Rec. 2013, 13, 43-59. doi:10.1002/tcr.201200012 
24. Li, D.; Qu, X.; Newton, S. M. C.; Klebba, P. E.; Mao, C. J. Mater. Chem. 2012, 22, 15702-15709. doi:10.1039/c2jm31034a

25. Niu, Z.; Liu, J.; Lee, L. A.; Bruckman, M. A.; Zhao, D.; Koley, G.; Wang, Q. Nano Lett. 2007, 7, 3729-3733. doi:10.1021/nl072134h

26. Royston, E. S.; Brown, A. D.; Harris, M. T.; Culver, J. N. J. Colloid Interface Sci. 2009, 332, 402-407. doi:10.1016/j.jcis.2008.12.064

27. Aljabali, A. A. A.; Barclay, J. E.; Cespedes, O.; Rashid, A.; Staniland, S. S.; Lomonossoff, G. P.; Evans, D. J. Adv. Funct. Mater. 2011, 21, 4137-4142. doi:10.1002/adfm.201101048

28. Rothenstein, D.; Facey, S. J.; Ploss, M.; Hans, P.; Melcher, M.; Srot, V.; Van Aken, P. A.; Hauer, B.; Bill, J. Bioinspired, Biomimetic Nanobiomater. 2013, 2, 173-185. doi:10.1680/bbn.13.00004

29. Evans, D. J. Biochem. Soc. Trans. 2009, 37, 665-670. doi:10.1042/BST0370665

30. Dujardin, E.; Peet, C.; Stubbs, G.; Culver, J. N.; Mann, S. Nano Lett. 2003, 3, 413-417. doi:10.1021/nl034004o

31. Yang, C.; Choi, C.-H.; Lee, C.-S.; Yi, H. ACS Nano 2013, 7, 5032-5044. doi:10.1021/nn4005582

32. Knez, M.; Sumser, M. P.; Bittner, A. M.; Wege, C.; Jeske, H.; Hoffmann, D. M. P.; Kuhnke, K.; Kern, K. Langmuir 2004, 20, 411-447. doi:10.1021/la035425o

33. Fujikawa, S.; Kunitake, T. Langmuir 2003, 19, 6545-6552. doi:10.1021/la026979e

34. Royston, E.; Lee, S.-Y.; Culver, J. N.; Harris, M. T. J. Colloid Interface Sci. 2006, 298, 706-712. doi:10.1016/j.jcis.2005.12.068

35. Chiang, C.-Y.; Epstein, J.; Brown, A.; Munday, J. N.; Culver, J. N.; Ehrman, S. Nano Lett. 2012, 12, 6005-6011. doi:10.1021/nl303579z

36. Mao, C.; Solis, D. J.; Reiss, B. D.; Kottmann, S. T.; Sweeney, R. Y.; Hayhurst, A.; Georgiou, G.; Iverson, B.; Belcher, A. M. Science 2004, 303, 213-217. doi:10.1126/science.1092740

37. Atanasova, P.; Rothenstein, D.; Schneider, J. J.; Hoffmann, R. C.; Dilfer, S.; Eiben, S.; Wege, C.; Jeske, H.; Bill, J. Adv. Mater. 2011, 23 , 4918-4922. doi:10.1002/adma.201102900

38. Balci, S.; Bittner, A. M.; Schirra, M.; Thonke, K.; Sauer, R.; Hahn, K.; Kadri, A.; Wege, C.; Jeske, H.; Kern, K. Electrochim. Acta 2009, 54, 5149-5154. doi:10.1016/j.electacta.2009.03.036

39. Atanasova, P.; Stitz, N.; Sanctis, S.; Maurer, J. H. M.; Hoffmann, R. C.; Eiben, S.; Jeske, H.; Schneider, J. J.; Bill, J. Langmuir 2015, 31 , 3897-3903. doi:10.1021/acs.langmuir.5b00700

40. Adams, M. J.; Heinze, C.; Jackson, A. O.; Kreuze, J. F.; MacFarlane, S. A.; Torrance, L. Family Virgaviridae. In Virus taxonomy: Ninth report of the International Committee on Taxonomy of Viruses; King, A. M. Q.; Adams, M. J.; Carstens, E. B.; Lefkowitz, E. J., Eds.; Elsevier: San Diego, CA, U.S.A., 2012; pp 1139-1162.

41. Culver, J. N. Annu. Rev. Phytopathol. 2002, 40, 287-308. doi:10.1146/annurev.phyto.40.120301.102400

42. Butler, P. J. G. Philos. Trans. R. Soc., B 1999, 354, 537-550. doi:10.1098/rstb.1999.0405

43. Namba, K.; Pattanayek, R.; Stubbs, G. J. Mol. Biol. 1989, 208, 307-325. doi:10.1016/0022-2836(89)90391-4

44. Ge, P.; Zhou, Z. H. Proc. Natl. Acad. Sci. U. S. A. 2011, 108, 9637-9642. doi:10.1073/pnas.1018104108

45. Clare, D. K.; Orlova, E. V. J. Struct. Biol. 2010, 171, 303-308. doi:10.1016/j.jsb.2010.06.011

46. Sachse, C.; Chen, J. Z.; Coureux, P. D.; Stroupe, M. E.; Fändrich, M.; Grigorieff, N. J. Mol. Biol. 2007, 371, 812-835.

doi:10.1016/j.jmb.2007.05.088
47. Alonso, J. M.; Górzny, M. Ł.; Bittner, A. M. Trends Biotechnol. 2013, 31, 530-538. doi:10.1016/j.tibtech.2013.05.013

48. Culver, J. N.; Brown, A. D.; Zang, F.; Gnerlich, M.; Gerasopoulos, K.; Ghodssi, R. Virology 2015, 479-480, 200-212. doi:10.1016/j.virol.2015.03.008

49. Schlick, T. L.; Ding, Z.; Kovacs, E. W.; Francis, M. B. J. Am. Chem. Soc. 2005, 127, 3718-3723. doi:10.1021/ja046239n

50. Smith, M. L.; Lindbo, J. A.; Dillard-Telm, S.; Brosio, P. M.; Lasnik, A. B.; McCormick, A. A.; Nguyen, L. V.; Palmer, K. E. Virology 2006, 348, 475-488. doi:10.1016/j.virol.2005.12.039

51. Eiben, S.; Stitz, N.; Eber, F.; Wagner, J.; Atanasova, P.; Bill, J.; Wege, C.; Jeske, H. Virus Res. 2014, 180, 92-96. doi:10.1016/j.virusres.2013.11.019

52. Shukla, S.; Eber, F.; Nagarajan, A. S.; DiFranco, N. A.; Schmidt, N.; Wen, A. M.; Eiben, S.; Twyman, R. M.; Wege, C.; Steinmetz, N. F. Adv. Healthcare Mater. 2015, 4, 874-882. doi:10.1002/adhm.201400641

53. Eber, F. J.; Eiben, S.; Jeske, H.; Wege, C. Angew. Chem., Int. Ed. 2013, 52, 7203-7207. doi:10.1002/anie.201300834

54. Eber, F. J.; Eiben, S.; Jeske, H.; Wege, C. Nanoscale 2015, 7, 344-355. doi:10.1039/C4NR05434B

55. Baio, J. E.; Zane, A.; Jaeger, V.; Roehrich, A. M.; Lutz, H.; Pfaendtner, J.; Drobny, G. P.; Weidner, T. J. Am. Chem. Soc. 2014, 136, 15134-15137. doi:10.1021/ja5078238

56. Zane, A. C.; Michelet, C.; Roehrich, A.; Emani, P. S.; Drobny, G. P. Langmuir 2014, 30, 7152-7161. doi:10.1021/la501444t

57. Cha, J. N.; Shimizu, K.; Zhou, Y.; Christiansen, S. C.; Chmelka, B. F.; Stucky, G. D.; Morse, D. E. Proc. Natl. Acad. Sci. U. S. A. 1999, 96, 361-365. doi:10.1073/pnas.96.2.361

58. Kröger, N.; Deutzmann, R.; Sumper, M. Science 1999, 286, 1129-1132. doi:10.1126/science.286.5442.1129

59. Poulsen, N.; Kröger, N. J. Biol. Chem. 2004, 279, 42993-42999. doi:10.1074/jbc.M407734200

60. Rothenstein, D.; Claasen, B.; Omiecienski, B.; Lammel, P.; Bill, J. J. Am. Chem. Soc. 2012, 134, 12547-12556. doi:10.1021/ja302211w

61. Kuno, T.; Nonoyama, T.; Hirao, K.; Kato, K. Langmuir 2011, 27 , 13154-13158. doi:10.1021/la202576v

62. Stöber, W.; Fink, A.; Bohn, E. J. Colloid Interface Sci. 1968, 26, 62-69. doi:10.1016/0021-9797(68)90272-5

63. Kim, Y. J.; Hwang, K. H.; Park, S.-J.; Jeon, D.-Y.; Nam, C.-H.; Kim, G.-T. J. Nanosci. Nanotechnol. 2013, 13, 6203-6207. doi:10.1166/jnn.2013.7683

64. Fowler, C. E.; Shenton, W.; Stubbs, G.; Mann, S. Adv. Mater. 2001, 13, 1266-1269. doi:10.1002/1521-4095(200108)13:16<1266::AID-ADMA1266>3.0.CO; 2-9

65. Rong, J.; Oberbeck, F.; Wang, X.; Li, X.; Oxsher, J.; Niu, Z.; Wang, Q. J. Mater. Chem. 2009, 19, 2841-2845. doi:10.1039/b901130g

66. Mueller, A.; Eber, F. J.; Azucena, C.; Petershans, A.; Bittner, A. M.; Gliemann, H.; Jeske, H.; Wege, C. ACS Nano 2011, 5, 4512-4520. doi:10.1021/nn103557s

67. Chen, X.; Gerasopoulos, K.; Guo, J.; Brown, A.; Ghodssi, R.; Culver, J. N.; Wang, C. Electrochim. Acta 2011, 56, 5210-5213. doi:10.1016/j.electacta.2011.03.037

68. Li, F.; Wang, Q. Small 2014, 10, 230-245. doi:10.1002/smll.201301393

69. Luckanagul, J.; Andrew Lee, L.; Nguyen, Q. L.; Sitasuwan, P.; Yang, X.; Shazly, T.; Wang, Q. Biomacromolecules 2012, 13, 3949-3958. doi:10.1021/bm301180c 
70. Wu, Z.; Mueller, A.; Degenhard, S.; Ruff, S. E.; Geiger, F.; Bittner, A.; Wege, C.; Krill, C. E., III. ACS Nano 2010, 4, 4531-4538. doi:10.1021/nn100645e

71. Luckanagul, J. A.; Lee, L. A.; You, S.; Yang, X.; Wang, Q. J. Biomed. Mater. Res., Part A 2015, 103, 887-895. doi:10.1002/jbm.a.35227

72. Patwardhan, S. V.; Emami, F. S.; Berry, R. J.; Jones, S. E.; Naik, R. R.; Deschaume, O.; Heinz, H.; Perry, C. C. J. Am. Chem. Soc. 2012, 134, 6244-6256. doi:10.1021/ja211307u

73. Steinmetz, N. F.; Shah, S. N.; Barclay, J. E.; Rallapalli, G.; Lomonossoff, G. P.; Evans, D. J. Small 2009, 5, 813-816. doi:10.1002/smll.200801348

74. Gebauer, D.; Kellermeier, M.; Gale, J. D.; Bergström, L.; Cölfen, H. Chem. Soc. Rev. 2014, 43, 2348-2371. doi:10.1039/c3cs60451a

75. Almora-Barrios, N.; Austen, K. F.; de Leeuw, N. H. Langmuir 2009, 25, 5018-5025. doi:10.1021/la803842g

76. Geiger, F. C.; Eber, F. J.; Eiben, S.; Mueller, A.; Jeske, H.; Spatz, J. P.; Wege, C. Nanoscale 2013, 5, 3808-3816. doi:10.1039/c3nr33724c

77. Protein Calculator V3.4. http://protcalc.sourceforge.net (accessed May 27, 2015).

78. ImageJ software; 2011, http://imagej.nih.gov/ij/.

79. Hong, J. H.; Duncan, S. E.; Dietrich, A. M. Food Qual. Prefer. 2010, 21, 132-139. doi:10.1016/j.foodqual.2009.08.010

80. Hunter, R. J. Zeta potential in colloid science: principles and applications; Academic Press: London, United Kingdom, 1981.

81. Müller, R. H.; Hildebrand, G. E., Eds. Zetapotential und Partikelladung in der Laborpraxis: Einführung in die Theorie praktische Messdurchführung Dateninterpretation, Colloidal Drug Carriers - cdc 1st Expert Meeting, Berlin, Germany, June 15-17, 1995; Wissenschaftliche Verlagsgesellschaft: Stuttgart, Germany, 1995.

82. Reed, J. S. Principles of ceramics processing, 2nd ed.; John Wiley \& Sons, Inc.: New York, NY, U.S.A., 1995.

83. Niu, Z.; Kabisatpathy, S.; He, J.; Lee, L. A.; Rong, J.; Yang, L.; Sikha, G.; Popov, B.; Emrick, T.; Russell, T.; Wang, Q. Nano Res. 2009, 2, 474-483. doi:10.1007/s12274-009-9043-6

84. Bruckman, M. A.; Soto, C. M.; McDowell, H.; Liu, J. L.; Ratna, B. R.; Korpany, K. V.; Zahr, O. K.; Blum, A. S. ACS Nano 2011, 5, 1606-1616. doi:10.1021/nn1025719

85. Kadri, A.; Maiß, E.; Amsharov, N.; Bittner, A. M.; Balci, S.; Kern, K.; Jeske, H.; Wege, C. Virus Res. 2011, 157, 35-46. doi:10.1016/j.virusres.2011.01.014

86. Altunbas, A.; Sharma, N.; Lamm, M. S.; Yan, C. Q.; Nagarkar, R. P.; Schneider, J. P.; Pochan, D. J. ACS Nano 2010, 4, 181-188. doi:10.1021/nn901226h

87. Acar, H.; Garifullin, R.; Guler, M. O. Langmuir 2011, 27, 1079-1084. doi:10.1021/la104518g

88. Sumper, M.; Kröger, N. J. Mater. Chem. 2004, 14, 2059-2065. doi:10.1039/b401028k

89. Filner, B.; Marcus, A. Virology 1974, 61, 537-546. doi:10.1016/0042-6822(74)90288-8

90. Belu, A. M.; Graham, D. J.; Castner, D. G. Biomaterials 2003, 24, 3635-3653. doi:10.1016/S0142-9612(03)00159-5

91. Gooding, G. V.; Hebert, T. T. Phytopathology 1967, 57, 1285.

92. Bruckmann, M. A.; Steinmetz, N. F. Chemical Modification of the Inner and Outer Surfaces of Tobacco Mosaic Virus (TMV). In Virus hybrids as nanomaterials: methods and protocols; Lin, B.; Ratna, B., Eds.; Methods in Molecular Biology, Vol. 1108; Humana Press: New York, NY, U.S.A., 2014; pp 173-185. doi:10.1007/978-1-62703-751-8_13
93. Bruckman, M. A.; Jiang, K.; Simpson, E. J.; Randolph, L. N.; Luyt, L. G.; Yu, X.; Steinmetz, N. F. Nano Lett. 2014, 14, 1551-1558. doi:10.1021/nl404816m

94. Description of Plant Viruses. http://www.dpvweb.net/dpv/showdpv.php?dpvno=370 (accessed May 27, 2015).

95. Laemmli, U. K. Nature 1970, 227, 680-685. doi:10.1038/227680a0

96. Green, M. R.; Sambrook, J. Molecular cloning: a laboratory manual, 4th ed.; Cold Spring Harbor Laboratory Press: New York, NY, U.S.A., 2012.

\section{License and Terms}

This is an Open Access article under the terms of the Creative Commons Attribution License

(http://creativecommons.org/licenses/by/2.0), which permits unrestricted use, distribution, and reproduction in any medium, provided the original work is properly cited.

The license is subject to the Beilstein Journal of

Nanotechnology terms and conditions:

(http://www.beilstein-journals.org/bjnano)

The definitive version of this article is the electronic one which can be found at: doi:10.3762/bjnano.6.145 